\title{
Queer Theories, Critiques and Beyond
}

\section{Af Christel Stormhøj}

Which philosophical traditions of critique does queer thought feed on, and what problems inhere in them; what are the objects and aims of critique offered by queer thinkers; and how do they imagine, if at all, the ordering of the social world beyond the negative moment of critique?

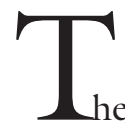

he term 'queer' means across, and is construed by queer theory as referring to that which runs transversely to the legitimate, or what is assumed to be the order of things. By definition, queer delineates a critical positionality vis-à-vis the normative. ${ }^{1}$ Queer thought, then, is a critical enterprise. But what does this mean, and what is critique? Critique is generally defined as the art of passing judgement on something (knowledge, culture, politics) with reference to some standard - of rightness or efficiency, for example (Koselleck 1979; Sinnerbrink et al. 2006). These standards may be external or internal to the object of critique; be stated explicitly or remain implicit to the judgements made; have strong or weak normative grounds; and be claimed as universally valid or merely contextually applicable. As I will show, queer theory endorses various standards, most of which bracket issues of normative foundations by suspending judgement. 
My aim is to explore and discuss queer as critique focusing on the theory side of queer. I base my examination on a series of parallel readings of leading queer thinkers, including Judith Butler, Eve Sedgwick, and Michael Warner. ${ }^{2}$ To my knowledge, no academic literature in the Nordic countries has examined this issue methodically using an all-encompassing philosophical (theoretical and political) approach. Focusing on social critique, ${ }^{3}$ which pertains to standards of what is right and good, I sketch out the philosophical traditions and strategies of social critique that provide the context in which queer as critique emerges (part I). In addition, I consider some of the dilemmas and unresolved problems of these modes of critique. Part II explores how queer functions as a critique of the social, interrogating dominant knowledges, social hierarchies, and established norms around sex, gender and sexuality. In doing so I investigate in more detail the objects and aims of queer critiques, along with scrutinising how queer thinkers contend with the pitfalls that haunt their cherished modes of critique. Part III examines the link between the negative moment of critique - i.e. attempts to shed stifling forms of thought, power and practice - and the positive moment, with the latter pointing towards queer political visions and their ethicopolitical underpinnings.

\section{PHILOSOPHICAL TRADITIONS AND STRATEGIES OF SOCIAL CRITIQUE}

If we are to gain a more thorough insight into queer as critique, it is imperative to consider the strands of critical philosophy informing queer theory. My argument is that queer forms of critique are premised on the Hegelian/Marxist tradition of dialectic as immanent critique, and on the Nietzschean/late Wittgensteinian practice of what I will call critique as intervention. Recognizing this historical legacy helps to achieve a better understanding of the prin- cipal modes of critique at work in queer theory, as well as some of the strengths and inherent flaws that queer inevitably inherits. ${ }^{4}$ Within the tradition of immanent critique, lines of descent can be drawn from Hegel-Marx-Derrida to two modes of queer critique: deconstruction, and the critique of ideology. In terms of critique as intervention, we may identify two separate lines of descent. One line links queer's practice of genealogical critique with Nietzsche and Foucault. Another line can be drawn from Nietzsche-the late Wittgenstein-Rorty to queer's practice of innovative re-description as critique. These two traditions - of immanent critique and critique as intervention - frame the key strategies of critique applied by queer thought, often rather idiosyncratically and based on only part of each tradition, in accordance with its own guiding impulses. ${ }^{5}$

Immanent critique presupposes that it is possible to criticise a particular symbolic and/or social formation in the name of a standard that this formation contains within itself. 6 This strategy aims to identify and locate inconsistencies within the premises necessary for the production of these formations. ${ }^{7}$ The idea of dialectic resolution is central to Hegel's $(1972 ; 1977)$ critique, which is based on the understanding that every thought is one, incomplete, stage in the unfolding of the Absolute Idea. Engaging with the oppositions found in existing philosophies, he claims that, instead of conflicting with each other, the two terms of a binary are interrelated: they depend on each other. Moreover, both terms are actually congruent with one another once brought together and lifted up on a higher stage, a process described as 'sublation'. Difference (negativity), then, is incorporated into identity when the Absolute Idea is realized.

Relating to Hegel's notion of dialectic, Marx (1967) develops his own mode of critique, focusing on the contradictions of capitalism and the ideological forms of 
knowledge associated with this social formation. ${ }^{8}$ (The young) Marx's critique of ideology reveals what is hidden: the exploitation of workers, exposing the disparity between ideology and reality and locating this contradiction as endemic to reality itself. Praxis (class struggle) and critical theory serve as tools for overcoming capitalism. His critique, then, is political, allying itself with the workers' movement in order to assist it towards self-emancipation through the clarification of its interests (Marx 1978).

There is an built-in dilemma in these modes of critique: they can only question particular formations by appealing to particular standards; such criteria, however, are likely to be understood as external to the formation under scrutiny. The critic thus tends to present her standards as universal, i.e. to occlude their contingent nature (Boer 2012: 96).9 Though appearing not to supply her own standards, the critic is actually implicated in producing them. The implication of such moves is that the strict division between internal and external critique cannot be maintained.

Derridean $(1976 ; 1988)$ deconstruction is a third version of immanent critique, aiming to expose, and then destabilize, the various binary oppositions on which dominant thought is based. This strategy contends that our basic binaries are unstable; they are always already troubled, i.e. characterized by undecidability. Ostensibly oppositional terms are inextricably interrelated, and their implied hierarchies reversible. They are thus both arbitrary and politically instituted.

Apparently, deconstruction is purely parasitic; yet, because it is linked negatively to the formation that it seeks to undo, it is haunted by a paradox. Like this structure, it cannot but implicitly articulate and perform value commitments, if only extremely thin ones. It retrieves difference - in the notion of the critical force of negativity - as a resource that may help to lessen the vio- lence of closure implied in our dominant ways of thinking. As such, deconstruction may contain resources for an account of normativity.

Critique as intervention operates by redescribing the object of investigation in unusual terms, and from unfamiliar perspectives, in order to transform the ways we think about it. Nietzschean (1993) and Foucauldian (1984) genealogy, which is a historical form of critique, questions what appears in the present as stable or given by showing how such notions originated in power struggles, and hence are contingent. Re-presenting the object in a parodying or dramatic form, what is distinctive lies in the critical effect: the provocation of a sense of astonishment in the audience that may disturb our certainties and elicit existential self-reflection (Saar 2009). This strategy also suggests that certain aspects of the present are problematic and in need of change. Instead of using explicit norms to make judgements, genealogy presupposes a set of values (individual rights and freedoms) that we already take seriously; however, because it aims at provoking discomfort, it also encourages us to question them. Finally, as a critical act, genealogy is always re-active, a counter-attack: "the art of not being governed like that" (Foucault 2002: 193).

There are problems related to this mode of critique that cannot be settled. An important one concerns the normative grounds of the criteria used. While Foucault makes judgements about current practices of power by repeatedly pointing to the dangers associated with them, he refrains from clarifying the norms that ground these evaluative aspects of his critique. Therefore critics, such as Bernstein (1995) and Habermas (1987), have charged him with 'cryptonormativism'. If Foucault were to rebut this objection, they argue, his conception of danger would require some independent warrant. However, there are other ways to interpret his critical thinking that make sense of it on its own premises, 
though they do not necessarily protect him against criticism. Here, I will only be able to suggest two readings: (i) His critical enterprise is mainly negativistic, articulating a dystopic diagnosis of modernity that focuses on its inherent dangers, which he associates with extensive normalization. ${ }^{10}$ We can only know the stifling forms of power, thought, and practice that circumscribe our modes of being, but nothing beyond them, as, in his view, socialization goes the whole way through. Knowledge of these limits is sufficient to underpin his critical thinking. (ii) As in Derridean deconstruction, Foucault displays the aporetic situation of critique. ${ }^{11}$ Critique is, like the practices of power that it targets, itself contingently conditioned, and in interrogating certain value commitments cannot but posit values itself. This may explain why genealogy at once presupposes and challenges the values we (and Foucault himself) already hold. We have no other alternative than these normative commitments due to our social and historical embeddings; yet, these commitments are nevertheless subject to change.

In Rorty (1989), pragmatic critique is framed as innovative re-description. As in Nietzsche and Wittgenstein's later work, he claims that scientific vocabularies are tools for coping: their truth claims are to be decided as to the purposes they serve in practice. Pragmatic thought provides the best resources for inventing new ways of thinking and acting that can be used to reduce suffering and assist us in clarifying social goals and the ways to achieve them. Any value commitment (including, of course, Rorty's own liberalism) is a historical contingency and as such without any universal normative foundation. Liberals whose key imperative is to combat violence promote their cause through convincing redescriptions and 'humanizing' narratives, in terms that are comprehensible given community based understandings. As in genealogical critique, a problem with this strategy of cri- tique arises from its normative basis, which may suggest to some that Rorty advocates a kind of relativism. We should rather imagine his critical thinking as a normative contextualism that rejects the possibility of transcendental strategies of justification. We only have access to context-dependent warrants because we cannot take up standpoints that transcend our social and historical context.

\section{QUEER CRITIQUES}

Generally, queer thought interrogates normative notions of sex, gender, and sexuality. As a corollary it is critical of those forms of identity, community, and politics which are believed to grow naturally from such ideas, whether deployed in the service of the consolidation of the heterosexual imperative, or by the mainstream of the gay and lesbian community.

Though it is impossible to summarize the multiple strands of critical thought that queer theory (itself a heterogeneous body of work) feeds on, I suggest that the best way to conceive queer theory - along with its antecedents, twentieth-century continental poststructuralism and analytical philosophy, including Rorty's pragmatism - is as an anti- or critical philosophical position, defined primarily by what it rejects. ${ }^{12}$ In epistemology queer thought endorses antifoundationalism (there is no philosophical grounding for our knowledge); in philosophy of language anti-representationalism (language is an activity that produces meaning in a performative manner, as well as a tool for coping rather than a representation mirroring reality); and in metaphysics anti-essentialism (there is no real, true essence of things - no invariable properties that define what any given thing is). ${ }^{13}$ By implication, this means that queer thinking is always marginal to the tradition of western philosophy, operating through lines of counter-thought. It is much more an interrogative than a normative mode of 
inquiry, challenging established notions and norms instead of offering solutions and blueprints. How does 'theoretical' queer thought conceive the practice of critique?

Despite their different theoretical affiliations, the three leading queer thinkers, Sedgwick, Warner, and Butler, share certain notions of critique: (i) Critique has transformation as one of its main goals. (ii) (Queer) theory is itself transformative. Intervening in the politics of knowledge, it interrogates that which is assumed to be the order of things to expose the limitations, contingencies and instabilities of our dominant ontological and epistemological certainties. Queer critique is suspicious of efforts to be normative: any such attempts may be products of prevailing power/ knowledge relations, such that our epistemological frames may sustain ways of structuring the social world that preclude alternative possibilities of ordering. (iii) Theoretical and practical critique is more or less intertwined. (iv) There is an ethical dimension to their projects, such that they are committed to beginning their inquiries from the margins. Queer inquiry responds to the violence that norms do to people who are engaged in non-conforming gender and sexual practices. Hence, (v) critique is a life-and-death struggle.

In what follows I engage with the two modes of critique (immanent critique and critique as intervention) elaborated in part I to look into both the objects and aims of critique offered by these scholars, and to explore how they wrestle with the dilemmas and unresolved problems carried over from their predecessors.

Sedgwick deploys deconstruction, as is particularly evident in Epistemology of the Closet (1990) and Tendencies (1993).14 Whether targeting our social-sexual regime as centred on the hetero/homo trope, or Western culture's epistemological frame as organized by binaries (such as secrecy/disclosure and public/private) which are intertwined with the hetero/homo opposition, she draws on immanent forms of critique. She repeatedly reveals not just contradictions and fractures where unity and consistency are said to reign, but the interdependency of the terms of such oppositions. Our sexual definitions rest on sinking sands, moving unevenly between contradictory poles. In the case of the hetero/homo figure, the minoritizing strategy holds that this definitional knot has importance for a delimited minority group only, the group named and classified as homosexuals by the 'psy-sciences'. In contrast, the universalizing strategy claims that this knot is of determinative importance to people across the spectrum of sexuality. The very instability of the hetero/homo sexual definition makes it a privileged site for deconstruction (ibid. 1990: 10). This is, however, only one aspect of her critical aim, which is to dislocate the staying power of heterosexism. The other side is to reveal how reductive it is to define sexual orientation by the gender of one's object choice alone (ibid. 1990: 25). Making the hetero/homo figure into the core organizing principle of the socio-sexual domain implies that other possible dimensions of the sexual are ignored. In contrast to the ensemble of 'psysciences' and bio-political measures that produces this compulsion to classify, evaluate and regulate selves and populations according to this opposition, Sedgwick suggests - in line with deconstruction's 'principle' of différence - that people differ from each other sexually and in other ways (ibid. 1993: 2). ${ }^{15}$ Aware that deconstruction is far from sufficient to disable the workings of this regime, she stresses the importance of practical politics. As I read her, she points towards a Marxist conception of critique as politically engaged. The gay movements of the 20th century have stated their case, she claims, along two parallel lines: the minority and the universalist line. But the theoretical quandaries that deconstruction led us to (in her perspective, the priority of the universalizing view - the queer view - over 
the minoritizing view actually depends on the latter to get off the ground) echo the central dilemma found at the level of politics. This dilemma consists, on the one hand, of the impulse to reject identifying with established sexual categories, and, on the other, of the feeling that these categories represent important resources individually and politically (ibid. 1990: 13). While I agree with Sedgwick that the minority-model merely targets 'the symptoms' of heteronormativity 16 - the misrecognition of non-heterosexual practices and relations - and that the universalist-model goes to the very heart of this system, it seems unclear what force she attributes to the latter. What are the actual accomplishments of a politics based on refutation to identify with such categories - and as they are performed by whom, where and when? If rebellion against the fixity of identities is celebrated for its own sake, it degenerates into an empty gesture, and its transformative force becomes null and nix. If a queer politics is to be effective, 17 it requires access to multiple discursive resources and voices, the formation of alliances with culturally elite groups which can offer advocacy, and broad mobilizations of civil society.

In the programmatic introduction to Fear of a Queer Planet (1993), Warner engages in immanent critique as elaborated by (the young) Marx. Anchored in the actual experiences of queers in the present, 18 the task of queer theory is to clarify the agonizing question: what do queers want? (ibid. 1993: vii). Queer thought aims to both analyse and criticise the ways in which institutions, social practices and systems of knowledge operate to privilege heterosexuality and subordinate non-conforming modes of sexual desire, practice and relations. In order to dislodge this privilege Warner urges queer theorists to demystify heterosexual ideology in its many forms, 19 including the naturalisation of heterosexuality, het culture's ability to represent itself as society, and the equation of the human with the heterosexual. Such ideology legitimizes the prevailing heterosexual order by masking the unequal valorisation of sexual groups and dissimulating the real contradictions between heterosexuals and nonheterosexuals (ibid. 1993: xix). The task of queer theory, then, is to re-describe the social world in another vocabulary - one that unmasks these unequal relations of power. The inconsistencies in how things really are, and the distortion of reality engendered by het ideology, provides the ground for immanent (queer) critique. Though lacking a satisfactory analysis of the causes of heterosexism and of the social position of non-heterosexuals, Warner (1993: xxv) argues that in modern societies sexuality defines a political interest-constituency that is more like a status group than a class. As an engaged form of critique, Warner's critique is linked to the struggles and concerns of the queer political movements that oppose normalization. By his account, queer theory helps to conceptualize and promote their political claims and interests. Such interests may be concerned with what the best practice of combating queer bashing would be, or they may stem from visions of a queer life without suffering and alienations.

Remarkably, Warner appears to ignore the profound criticisms leveled at ideology critique as practiced by Marxist thought, though he raises objections to other basic Marxist premises (ibid. 1993: xxiii). Here, I shall concentrate on two such criticisms. First, the conception of ideology as a totalising set of notions that determine people's ways of thinking and acting has been rejected. Heterosexual ideology is not monolithic, does not operate in the same way in every context, and guides rather than determines consciousness. Second, ideology critique is based on untenable presuppositions at the level of philosophy of science assumptions that the social sciences and humanities today have, if not abandoned, then at least interrogated and modified. It 
assumes that: (i) people suffer from false consciousness and are unable to see 'real' reality; and (ii) that there is a truth behind ideology, which Marxist thought has privileged access to unmask. In my view, Warner's critique is weakened because he fails to leave behind the untenable distinction between 'ideology' and a form of thought (namely the Marxists' own) which escapes 'ideology'. Ironically, this failure implies that any kind of critical thinking (in this case, Warners' own) that does not take into account its own performative aspects becomes ideological. Ideology backfires as a boomerang. One way to solve this problem would be to substitute the concept of ideology with others such as discourse, interpretive schemes, etc., and to reconceptualise epistemological conflicts as struggles for discursive authority. Warner's framing of queer critique is also inconsistent in that his syncreticism of Marxist and poststructuralist theoretical premises seems indefensible. Rather than reconstructing key notions of one tradition on the premises of the other, he lumps them together.

Warner is aware of the divisions amongst self-identified gay/lesbian and queer activists (1993: xvii; 1999: 25f.), and deploys pragmatic critique to sort through the consequences of pursuing different types of politics based on correspondingly different vocabularies. Traditional gay and lesbian politics - centred on a notion of respectability and focused on gaining recognition may end up reinforcing the normalization of gays and lesbians. Queer politics, in contrast, takes up an anti-normative positioning vis-à-vis sexuality, gender and other regimes of power and discipline. Though such a politics is more difficult to pursue, due to the political context for framing claims - a context that recognizes the language of identity politics only - it is nevertheless urgent, he argues, if we are to resist normalization. Warner points out that identity politics may run counter to sheltering sexual diversity, and, when viewed from the high grounds of theory, this critique is warranted. When framed as a pragmatic critique, however, it is misplaced. Stated too categorically, it misses the messiness and complexity of politics, and risks overlooking the potential of reformist politics.

Butler engages in immanent and intervening critique. Using dialectic reasoning as a tool of immanent critique (though a post-Hegelian dialectic, which rejects the possibility of reaching a final resolution), she (1995: 129; 2000: 161) destabilises different universals (humanness, human rights etc.), ${ }^{20}$ claiming the impossibility of finally identifying any universal with any particular content. Analysing Vatican discourse on the human, she exposes a disparity between the ideals praised by this church - the sanctity of human life - and its actual treatment of what it itself labels as homosexuals' humanness. Insisting that the human is identical with the heterosexual, homosexuals are seen as less than human. By producing such a differential, the Vatican betrays its own claim on universality. Obviously, her project is to render the category of the human permanently open and contestable; but the force she claims for (this) immanent critique is unclear given the tremendous power held by the Vatican in human rights settings. And she is hardly impartial as to the standard of critique. Her own normative commitments (for instance to equality and precariousness) require a robust universalizing of rights, and she therefore includes the abjected in the category of the human to get her critique off the ground.21 At the level of theory, Butler's critique could be reinforced. One could point out that the hierarchy established by the Vatican between the universal and the particular, in which heterosexuality is associated with the former and homosexuality with the latter, is actually based on a decision that 'cancels' the undecidable play between the two terms. In principle, the priority of the universal over the particular could be reversed. In support of such a de- 
vice, one might argue that homosexuality is the condition of the possibility of heterosexuality, or simply that the latter is a supplement to it. ${ }^{22}$ Another way to add to the force of Butler's critic would consist of showing how the Vatican's discourse tends to conceive of its own particular criteria (derived from a sexual morality in which the heterosexual order is imposed by God) as a universal standard, and hence to dissimulate the contingent nature of these criteria. In short, such a critique would expose the false universality through which the Vatican attempts to hegemonize the human.

To destabilize the foundationalist notions of gender identity - those theories that assume that gender identity is a natural 'thing' - Butler engages in a genealogical critique of gender ontologies so as to "investigate[s] the political stakes in designating as an origin and cause those identity categories that are in fact the effects of institutions, practices, discourses" (1990: ix). One of the crucial regimes of power for maintaining such notions is the institution of compulsory heterosexuality, which represents males and females as 'the real' sexes rooted in an original heterosexuality and finds expression in oppositional feminine and masculine dispositions. ${ }^{23}$ As such, the power at work in the heterosexualisation of subjects is effectively masked. The task of her critique is to expose that power, which dissimulates as ontology, and to re-describe gender identity in a radically new way: as a process, ${ }^{24}$ a material constitution of the subject that takes place through a forcible reiteration of gender norms (Butler 1993). ${ }^{25}$ For her, all gender is a repetition, the 'ground' of which is a vanishing point (ibid. 1990: 136). Crucially, the becoming of a woman or a man (though this process enables precisely these identities) also does violence to all those genders which fail to comply with hegemonic heterosexual norms. The intended shock-effect of Butler's re-description concerns three issues:
The recognition of the genuinely political nature of gender; the violence that prevailing norms do to us; and the possibility of reworking those norms given the proper ontological groundlessness of sex. While Butler's use of genealogical critique appears productive in precisely this respect, it is, however, reductive as well. By focusing on philosophical texts alone she fails to account for the socio-cultural and historical conditions which both enable and limit the workings of heteronormativity, the very phenomenon that she is critically analysing.

In Undoing Gender (2004), Butler addresses the question of survival as it relates to the struggles of the new movement concerned with intersex. Considering the conflict between queer theory's tendency to reject identity categories (which are seen as having exclusionary and normalizing effects) and the intersex movement's insistence on the necessity of stable sex assignment, in order to protect the survival of intersex children, Butler practices pragmatic critique. In principle, a queer politics opposing normalization is preferable; still, in practice, intersex minors may need firm identities to function well (ibid. 2004: 8). Concurrently, she appreciates the intersex movement's criticism of coercive surgery that adjusts intersexed bodies to bipolar gender norms. Such balanced considerations seem reasonable. Deciding on the usefulness of identity categories becomes pragmatic, linked with a concern to reduce suffering.

\section{BEYOND THE NEGATIVE MOMENT OF CRITIQUE}

Does queer critique merely confront us with the misery and violence that our current social-sexual regime cannot but produce, without providing us with visions of more desirable futures based on alternative norms? If we were to believe critics who charge queer thought with political nihilism and quietism (e.g. Nussbaum [1999] 
and Seidman [1995]), this would be the case. True, queer is mainly an interrogative mode of inquiry, problematizing established notions and norms, and raising new sorts of questions about the historical contingencies that are always shaping us, limiting what we are. Despite the flaws I find in queer, this critical sting makes it extremely productive. Moreover, queer is not devoid of value commitments. If understood correctly, it contains unnoticed resources for normative accounts. Due to the aporetic situation of critique mentioned above, queer cannot but set norms itself when practicing critique. We might therefore ask how queer thinkers imagine the ordering of the social world, and to which norms they are committed. Here, I can only provide some tentative insights.

In praising existential singularity and difference, Sedgwick (1993: xiii) alludes to a wished-for order of social difference, the gain of which would be the protection of diversity. This vision, however, raises thorny ethical and political questions, including questions of ethical codes that can provide guidance as to which differences to preserve, and of the political principles needed to secure legitimate normative regulation. On these issues, Sedgwick has little to say. Warner (1999: lff) invokes a principle of sexual autonomy that enables people to manage the choices involved in their sexual lives themselves, without interference from the state, unless they violate the autonomy of others. A sexual ethics building on this principle is already present in queer political culture, allowing for sexual variance. The advantage of such an ethics, based on 'thin' value commitments (autonomy, consent, responsibility), lies in its ability to shelter the integrity of many sexual differences; still, there is a need to provide some warrants for these values. Why is selfdetermination a good? Because we consent to it as a mere product of our acculturation, as Rorty would argue? Warner is silent on this matter. Butler $(2002 ; 2004)$ argues for a politics of disobedient interrogation and of radical resignification of the hegemonic norms that circumscribe the domain of socially recognized bodies and relations. Behind these practices lies a normative commitment to broaden the category of the human and to end the violence of exclusion, unreality or annihilation. Her wished-for social order would allow the coexistence of different modes of living and arrange for their institutional support. Ethically, she advocates a responsibility to difference. At an institutional level, and related to the question of social justice, she speaks of a set of human capacities that are to be provided so as to enable us to function well; and with regard to government, she advocates a radical democratic frame for organizing public contestation of just norms. As I read her, she invokes a formalistic, minimalistically normative principle as justification, saying that human flourishing is a good. This ideal is deliberately vague and its meaning radically underdetermined: it simply tells us that we should create the conditions that enable collective and individual subjects to come into full existence and live a liveable life. If Butler is to improve her political theory it requires a clarification of the distinction between enabling and disabling norms, given the difficulties in separating normativity from normalization, and of the impossibility of universal inclusion given the need to minimize violence.

\section{Noter}

1. In queer thinking, the normative (and the derivative term, normativity) is a type of operation of power that establishes and promotes a set of norms of being and behaviour. Norms are operative at the level of subject-formation, as the subject comes into existence when assuming or embodying the norms of gender, sex etc. While I consider the 'normal' to be a statistical category, norms are 
morally established and have the force of imperatives, prescriptions and prohibitions.

2. Obviously, it is contestable, who the 'queens' of queer theory are. I have selected these three because of their crucial, though quite diverse, impact on the constitution of the field of queer theory, which from its very beginning has been US-based. One evidence of their influence is that newcomers in the field continue to quote and discuss their works.

3. The object of social critique is society (as a whole, or parts thereof, such as social conditions, institutions, forms of thought, practices etc.), and its normative structures.

4. Such acknowledgement may also serve as a healthy antidote to claims about the newness or originality of queer as a critical philosophical paradigm, staged as if it emerges ex nihilo. While I do see queer theory as an innovative approach, nonetheless, it is necessary to adopt a historical perspective, reminding us that queer modes of critique has a substantial history in philosophy. Apart from this distinct legacy that also includes poststructuralism, queer theory's insights derive from a number of sources, including feminist theory, lesbian and gay studies, and social science disciplines. For further discussion of the latter, see for example Seidman (1996), Walters (1996), and Schott (2003).

5 . As each strategy is characterized by a particular way of approaching the question about what is right and good, they are to be interpreted as modes of critique sui generis, implying that they are not mutually exclusive. The individual queer critic may deploy several of these simultaneously without running into contradictions.

6. Providing an exhaustive account of these strategies is beyond the scope of this article. Rather, I sketch their key premises and their associated form of critique.

7. In modern philosophy, Kant, of course, was the first to elaborate a schedule for immanent critique. Yet, he has no direct bearing on queer's conception of critical thought.

8. Marx alters the Hegelian frame radically, substituting materialism for idealism and replacing reason as such/spirit with real man, class struggle, and the tension between the forces and relations of production.

9. Both Hegel and Marx posit particular standards as universal, the former reason and the latter humanity and the overcoming of self-alienation. For a further elaboration, see Boer (2012).

10. Normalization is a type of operation of power that assesses modes of being and behaviour ac- cording to established norms. It is an association of bodily typologies with authorised knowledges and norms that operate to discipline, dispose and orient subjects.

11. The term 'aporetic' (deriving from aporia) means a problem, a difficulty, a quandary with no solution.

12. In my view, as indicated in the first section of this article, Rorty's position vis-à-vis traditional philosophy is quite similar to that of French poststructuralists. Both positions are developed in the wake of the linguistic turn.

13. For a more detailed elaboration, see Stormhøj (2006, in particular, chapter 2).

14. It should be noted, however, that Sedgwick, in her late phase, leaves deconstruction behind. In Touching Feeling (2003), she suggests a reparative reading program looking for the openings and moments of comfort that any text may offer. This schedule may secure the survival of queers better than a deconstructive critique.

15. Différence refers to the differing and deferring aspects involved in meaning making that ensures that meaning can never be definitively present.

16. Heteronormativity refers to the complex set of modes of understanding, knowledges both theoretical and practical, which make heterosexuality privileged and into a compulsory requirement. 17. Queer as a political mode of self-identification is notoriously difficult to define. Yet, I take it to refer to an identification with a political constituency mobilising around the term queer in order to contest the social dominance of heterosexuality.

18. See note 17.

19. (Heterosexual) ideology in the Marxist tradition refers to dominant forms of knowledge and belief that (i) in principle, covers everything from scientific knowledge, to religion, to everyday beliefs about proper conduct; (ii) distorts reality, and (iii) serves to legitimize status quo, in this case heterosexual dominance.

20. In Butler, the meaning of humanness is underdetermined. As a contested category, its meaning is set in competitions for discursive authority.

21 . Here, the abjected refers to those humans, which the Vatican calls homosexuals.

22. For Derrida, a supplement is something that, allegedly secondarily, comes to serve as an aid to something 'original' or 'natural'. That which is supplementary is always both an accretion and a substitution. We may think of, for example, masturbation as supplementary: it is never possible to desire the presence 'in person' before the play of substitution and the symbolic experience of auto- 
erotic. Therefore, in a sense, masturbation is 'originary'.

23. The term 'compulsory heterosexuality' was originally coined by Rich in the article, Compulsory Heterosexuality and Lesbian Existence (1980), in which she examines and criticizes heterosexuality as a political institution, as a normative requirement, maintained and legitimized by a series of common sense and theoretical forms of knowledge.

24. The notion of gender as a doing has itself a complex genealogy in feminist theory and social science disciplines, associated with the traditions of French existentialism, Marxist and psychoanalytical feminism, feminist anthropology, as well as symbolic interactionism and ethnometodology.

Butler's contribution consists in reformulating this idea within a unique syncretic approach that includes her theory of gender performativity.

25 . If successful, the heterosexualization of subjects produces intelligible genders, i.e. those genders, which institute and maintain relations of coherence and continuity among sex, gender, sexual practice, and desire.

\section{LITERATURE}

- Bernstein, Richard J. (1995): Foucault: Critique as a Philosophical Ethos, in: Michael Kelly (ed.): Critique and Power. Recasting the Foucault/ Habermas Debate. MIT Press, Cambridge, MA. - Boer de, Karin (2012): Hegel's Conception of Immanent Critique: Its Sources, Extent and Limit, in: Karin de Boer \& Ruth Sonderegger (eds.): Conceptions of Critique in Modern and Contemporary Philosophy. Palgrave Macmillan, New York. - Butler, Judith (1990): Gender Trouble. Feminism and the Subversion of Identity. Routledge, New York.

- Butler, Judith (1993): Bodies that Matter. On the Discursive Limits of 'Sex'. Routledge, New York. - Butler, Judith (1995): For a Careful Reading, in Seyla Benhabib, Judith Butler, Drucilla Cornel \& Nancy Fraser: Feminist Contentions. A Philosophical Exchange. Routledge, New York.

- Butler, Judith (2000): Competing Universalities, in Judith Butler, Ernesto Laclau \& Slavoj Zizek: Contingency, Hegemony, Universality. Contemporary Dialogues on the Left. Verso, London.

- Butler, Judith (2002): What is Critique? An Essay on Foucault's Virtue, in: David Ingram (ed.): The Political. Blackwell Publishers, Oxford.
. Butler, Judith (2004): Undoing Gender.

Routledge, New York.

- Derrida, Jacques (1978): Of Grammatology. John Hopkins University Press, Baltimore.

- Derrida, Jacques (1998): Limited Inc.

Northwestern University Press, Evanston.

. Foucault, Michel (1984): Nietzsche, Genealogy, History, in: Paul Rabinow (ed.): The Foucault

Reader. Penguin Books, London.

- Foucault, Michel (2002): What is Critique?, in:

David Ingram (ed.): The Political. Blackwell

Publishers, Oxford.

- Habermas, Jürgen (1987): The Philosophical

Discourse of Modernity. MIT Press, Cambridge,

MA.

- Hegel, G. W. F. (1972): Encyclopaedia of

Philosophical Sciences: The Logic. Oxford University Press, Oxford.

- Hegel, G. W. F. (1977): The Phenomenology of

Spirit. Oxford University Press, Oxford.

- Koselleck, Reinhardt (1979): Krise und Kritik:

Eine Studie zur Pathogenese der bürgerlichen Welt.

Suhrkamp Verlag, Frankfuth aM.

- Marx, Karl (1967): Writings of the Young Marx

on Philosophy and Society. Anchor Books, New

York.

- Marx, Karl (1978): Letter to Ruge, in Tucker,

Robert (ed.): The Marx - Engels Reader. Norton,

New York.

- Nietzsche, Friedrich (1993): Moralens oprindelse. Et stridsskrift. Det Lille Forlag, Frederiksberg.

- Nussbaum, Martha (1999): The Professor of

Parody, in: New Republic 1999/22.

- Rich, Adrienne (1980): Compulsory Heterosexuality and Lesbian Existence, in: Signs 1980/4.

- Rorty, Richard (1989): Contingency, irony, and solidarity. Cambridge University Press,

Cambridge.

- Saar, Martin (2009): Genealogische Kritik, in:

Rachel Jaeggi \& Tilo Wesche (H G.): Was ist

Kritik? Suhrkamp Verlag, Frankfurt aM.

- Schott, Robin M. (2003): Queer Theory: A

Feminist Philosophical Commentary, in: Kvinder,

Kon \& Forskning 2003/1.

- Sedgwick, Eve K. (1990): Epistemology of the

Closet. University of California Press, Berkeley.

- Sedgwick, Eve K. (1993): Tendencies. Duke

University Press, Durham, Md.

- Sedgwick, Eve K. (2003): Touching Feeling:

Affect, Pedagogy, Performativity. Duke University

Press, Durham, Md.

- Seidman, Steven (1995): Deconstructing Queer

Theory or the Under-theorization of the Social and the Ethical, in: Linda Nicholson \& Steven

Seidman (eds.): Social Postmodernism. Beyond 
Identity Politics. Cambridge University Press, Cambridge.

- Seidman, Steven (1996, Ed.): Queer Theory/ Sociology. Blackwell Publishers, Oxford.

- Sinnerbrink, Robert; Deranty, Jean-Philippe \& Smith, Nicholas (2006): Critique, Hope, Power: Challenges of Contemporary Critical Theory, in: Robert Sinnerbrink, Jean-Philippe Deranty, Nicholas Smith \& Peter Schmiedgen (eds.):

Critique Today. Brill, Boston.

- Stormhøj, Christel (2006): Poststrukturalismer videnskabsteori, analysestrategi, kritik. Samfundslitteratur, København.

- Walters, Suzanne D. (1996): "From Here to Queer: Radical Feminism, Postmodernism, and the Lesbian Menace (Or, Why Can't Woman Be More Like a Fag?), in: Signs 1996/4.

- Warner, Michael (1993): Introduction, in: Michael Warner (ed.): Fear of a Queer Planet. Queer Politics and Social Theory. University of Minnesota Press, Minneapolis.

- Warner, Michael (1999): The Trouble with Normal. Sex, Politics, and the Ethics of Queer Life. Harvard University Press, Cambridge, Mass.

\section{SUMMARY}

The article examines queer as critique by performing a series of parallel readings of leading queer thinkers, including Judith Butler, Eve Sedgwick, and Michael Warner. Introducing two philosophical traditions and strategies of social critique, immanent and intervening critique, along with their criteria of what is right and good, I discuss how these scholars engage in these strategies and wrestle with their in-built problems within the orbit of the research foci and ambitions of queer studies. Queer critique aims at challenging dominant knowledges, social hierarchies and norms related to sex, sexuality, and gender by exposing the limits they impose on us, including the sufferings associated with them. The article closes with considering queer political visions and their normative underpinnings.

Christel Stormhøj, Associate Professor, Ph.D

Department of Society and Globalisation Roskilde University 